\title{
Anisotropy in Hydrogen Embrittlement Resistance of Drawn Pearlitic Steel Investigated by in-situ Microbending Test during Cathodic Hydrogen Charging
}

\author{
Kota Tomatsu ${ }^{1)^{*}}$, Takafumi Amino'), Tetsushi $\mathrm{CHIDA}^{1)}$, Shunya $\mathrm{UsI}^{1)}$, Makoto OKonogi ${ }^{2)}$, \\ Hikaru KaWATA ${ }^{1)}$, Tomohiko OMURA ${ }^{3)}$, Naoki MaruYAmA ${ }^{1)}$ and Yoshitaka NishiYAmA ${ }^{1)}$ \\ 1) Advanced Technology Research Laboratories, Research \& Development, Nippon Steel Corporation \\ 2) Kimitsu R\&D Lab., Research \& Development, Nippon Steel Corporation \\ 3) Steel Research Laboratories, Research \& Development, Nippon Steel Corporation
}

Abstract: To investigate causes of superior hydrogen embrittlement resistance of drawn pearlitic steel, notched microcantilevers with different notch orientations were fabricated by focused ion beam, and microbending tests were conducted in air and during cathodic hydrogen charging by electrochemical nanoindentation. In air, indentation load increased with increase in indentation displacement, and no crack appeared for any notch orientations. During hydrogen charging, indentation load declined, and a crack appeared. The degree in the load reduction was larger, and the crack was deeper for the notch parallel to the lamellar interface than that normal to the lamellar interface. Furthermore, stationary cracks in the microcantilevers were observed by scanning electron microscopy and scanning transmission electron microscopy. For the notch parallel to the lamellar interface, a sharp long crack was identified along the lamellar interface. The crack stopped at the position where the cementite lamellae are disconnected. In lattice images, cementite was identified in one side of the crack, and ferrite in another side of the same crack. On the other hand, for the notch normal to the lamellar interface, a blunt short crack was identified. Thus, it was concluded that the ferrite-cementite interface is a preferential crack path, and hydrogen embrittlement resistance in the direction parallel to the lamellar interface is superior to that normal to the lamellar interface. The present results also indicate that directional lamellar alignment of the drawn pearlitic steel suppresses crack propagation in the radial direction of the drawn wire, improving the hydrogen embrittlement resistance in the drawing direction.

Keywords: nanoindentation; hydrogen embrittlement; bending test; focused ion beam; pearlite.
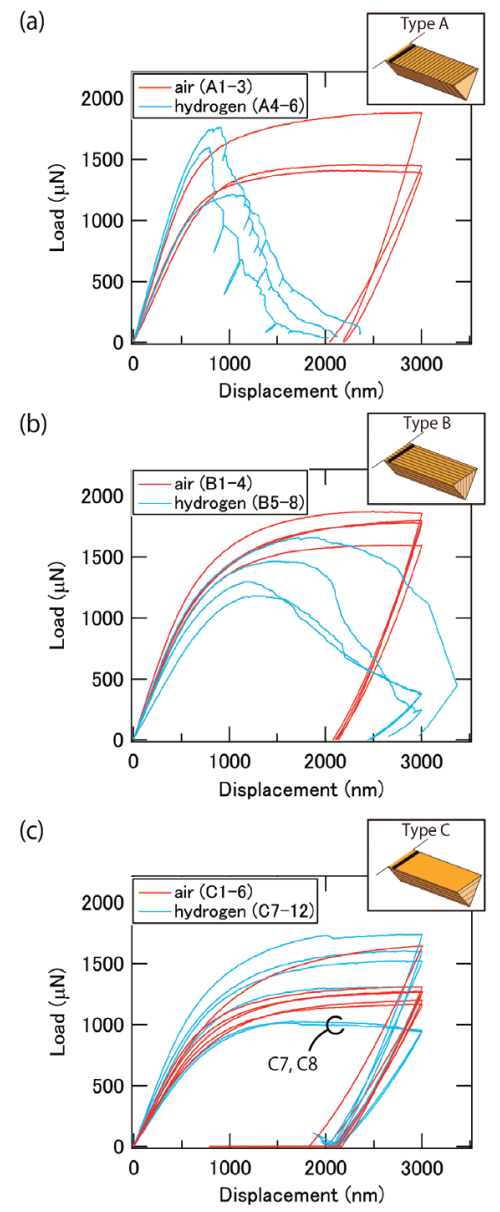

Received on Dec. 5, 2019 ; Accepted on Feb. 12, 2020 ; originally published in ISIJ Int., Vol.58, 2018, No.2, pp.340-348 and reprinted at the request of the ISIJ Editorial Board because the original paper received the Sawamura Award in March 2020.

* Corresponding author. E-mail : tomatsu.rk6.kohta@jp.nipponsteel.com, Address : Nippon Steel Corporation, 1-8 Fuso-cho Amagasaki Hyogo 660-0891 


\title{
電解水素チャージ下のその場微小曲げ試験法による 伸線パーライト鋼の水素脆化の異方性評価
}

\author{
富松 宏太 ${ }^{1)} \cdot$ 網野 岳文 ${ }^{1)} \cdot$ 千田 徹志 ${ }^{1)} \cdot$ 宇治 舜矢 ${ }^{1)}$. 小此木 真 ${ }^{2)} \cdot$ \\ 川田 光 $^{1)} \cdot$ 大村 朋彦 $^{3)} \cdot 丸 山$ 直紀 $^{1)} \cdot$ 西山 佳孝 ${ }^{1)}$
}

Anisotropy in Hydrogen Embrittlement Resistance of Drawn Pearlitic Steel Investigated by in-situ Microbending Test during Cathodic Hydrogen Charging

Kota Tomatsu, Takafumi Amino, Tetsushi Chida, Shunya Usi, Makoto OKonogi, Hikaru Kawata, Tomohiko Omura, Naoki Maruyama and Yoshitaka Nishiyama

\section{1. 背景}

伸線パーライト鋼の耐水素脆化 (Hydrogen Embrittlement: HE）性は同強度のマルテンサイト鋼に対して優れているこ とが知られている ${ }^{1,2)}$ 。パーライト鋼を冷間伸線加工すると, そのラメラ組織はラメラフェライト $(\alpha)$ とラメラセメンタ イト $(\theta)$ の界面が伸線軸と平行になるように配向する。こ のとき，ラメラ $\alpha$ 内では，転位密度が増加し，〈110〉結晶方 位が伸線軸と平行になるように集合組織が発達する ${ }^{3,4)}$ 。一 方，ラメラ $\theta$ 内では，結晶が断片化し，ナノ微細粒が形成さ れる ${ }^{5,6)}$ 。伸線パーライト鋼の優れた耐HE性は，このような 伸線方向に発達した繊維状のミクロ組織が HEき裂の伸線 材動径方向への進展を抑制することや，ラメラ $\alpha$ 内の高密 度の転位が水素をトラップし, HEき裂発生サイトへの水素 集積を抑制すること，にあると提案されている ${ }^{1,2)}$ 。

しかしながら，これらの機構を実験的に直接示した報告 はない。従来，伸線パーライト鋼の HEは，主に，低歪み速 度引張試験や定荷重引張試験などのマクロスケールの機械 試験によって研究されてきた ${ }^{1,2,7-11)}$ 。一般的に伸線材は細 く，これらの引張試験片を引張軸が伸線軸と垂直になるよ うに伸線材から採取することは困難である。このため，伸 線材の動径方向は伸線方向に比べ，耐HE性に関する知見 はほとんどない。また，HEき裂の伝播経路を特定するに は，走査電子顕微鏡 (Scanning Electron Microscopy：SEM)， さらに高空間分解能の走査透過電子顕微鏡 (Scanning Transmission Electron Microscopy：STEM）による停留き裂 の観察が不可欠である。しかし，上記のマクロスケールの
機械試験では，HEき裂発生後に直ちに試験片が破断する 場合が多く，停留き裂を得ることも困難である。HEき裂の 伝播経路についても理解は十分とは言えない。

一方，著者らは，電気化学ナノインデンテーション (Electrochemical Nanoindentation：EC-NI）装置を用いて， 電解水素チャージ下で微小片持ち梁 (Micro-cantilever： $\mathrm{MCL})$ に対して微小曲げ試験を実施し， $\mathrm{Ni}$ 基合金の個々の 粒界の耐 HE 性を明確化した ${ }^{12-15)}$ 。これらの MCL は収束イ オンビーム (Focused Ion Beam：FIB）により位置選択的に 試料表面に加工され，そのサイズは一般的なパーライトコ ロニー ( $\alpha-\theta$ 界面が同一方向に配向している領域 $)$ のイ ズと同程度である。さらに，曲げ変形では塑性拘束が働き， 引張変形に比べて発生したき裂は停留し易い。微小曲げ試 験を中断し，意図的に停留 HEき裂を形成することも可能 と予想される。このように, この電解水素チャージ下の微 小曲げ試験は，伸線パーライト鋼の HEに関して，異方性 やき裂伝播経路を調査するのに好適な解析手法と考えられ る。

そこで, 本研究では, 伸線パーライト鋼の表面に $\alpha-\theta$ 界 面に対する向きの異なる切欠き付 MCLを FIB加工した。そ して，これらの MCLに対してEC-NIにより大気下と電解 水素チャージ下で微小曲げ試験を実施した。さらに, 微小 曲げ試験で停留き裂を作製し，これらをSEM およびSTEM で観察した。

原著論文 : ISIJ Int., Vol.58 (2018), No.2, pp.340-348, 澤村論文賞受賞論文 (2020年表彰)

2019年12月5日受付２020年2月12日受理 (Received on Dec. 5, 2019 ; Accepted on Feb. 12, 2020 ; originally published in ISIJ Int., Vol.58, 2018, No.2, pp.340-348 and reprinted at the request of the ISIJ Editorial Board because the original paper received the Sawamura Award in March 2020.)

1）日本製鉄 (株) 技術開発本部先端技術研究所 (Advanced Technology Research Laboratories, Research \& Development, Nippon Steel Corporation)

2）日本製鉄 (株) 技術開発本部君津技術研究部 (Kimitsu R\&D Lab., Research \& Development, Nippon Steel Corporation)

3）日本製鉄 (株) 技術開発本部鉄鋼研究所 (Steel Research Laboratories, Research \& Development, Nippon Steel Corporation)

* Corresponding author. E-mail : tomatsu.rk6.kohta@jp.nipponsteel.com, Address : Nippon Steel Corporation, 1-8 Fuso-cho Amagasaki Hyogo 660-0891 


\section{2. 実験}

\section{$2 \cdot 1$ 供試材}

Table 1 に化学組成を示す直径 $6 \mathrm{~mm}$ のワイヤーロッド を供試材とした。ワイヤーロッドは，パテンチング処理と して，1223 Kに $600 \mathrm{~s}$ 間保持し，鉛浴を用いて $873 \mathrm{~K} に$ 急 冷した。さらに，直径 $4 \mathrm{~mm}$ に冷間伸線加工し，引張強度 $1.6 \mathrm{GPa}$ ，真歪み 0.81 の伸線パーライト鋼を得た。伸線パー ライト鋼は焼鈍せず，微小曲げ試験は伸線加工まま材に対 して実施した。

Fig.1に，作製した伸線パーライト鋼の伸線軸と平行な断 面 (L断面) のSEM像を示す。ラメラ組織が判別できるよ うに，表面はピクラール腐食している。過去の報告 ${ }^{3,4)}$ と一 致し， $\alpha-\theta$ 界面は概ね伸線方向と平行だった。また，平均ラ メラ間隔は約 $70 \mathrm{~nm}$ だった。

\section{$2 \cdot 2$ 実験方法}

作製した伸線パーライト鋼から直径 2-4 mm，厚さ $2 \mathrm{~mm}$ の円盤状の試験片を採取し, 盤面をバフ研磨と Arミリング により平坦化した。さらに，これらの鏡面研磨面に，Fig.2 （a）に示す断面が三角形の切欠き付 MCLを FIB加工した。 切欠きは30 keVのエネルギーの $\mathrm{Ga}^{+}$イオンビームを直線 的に走査することで加工した。この加工条件では，開き角 が約 $20^{\circ}$ のV字切欠きが得られ，その深さと先端部の曲率 はそれぞれ700 nm，40 nm 以下であった。

これらのMCLの加工位置は, Fig.2（b）に模式的に示す

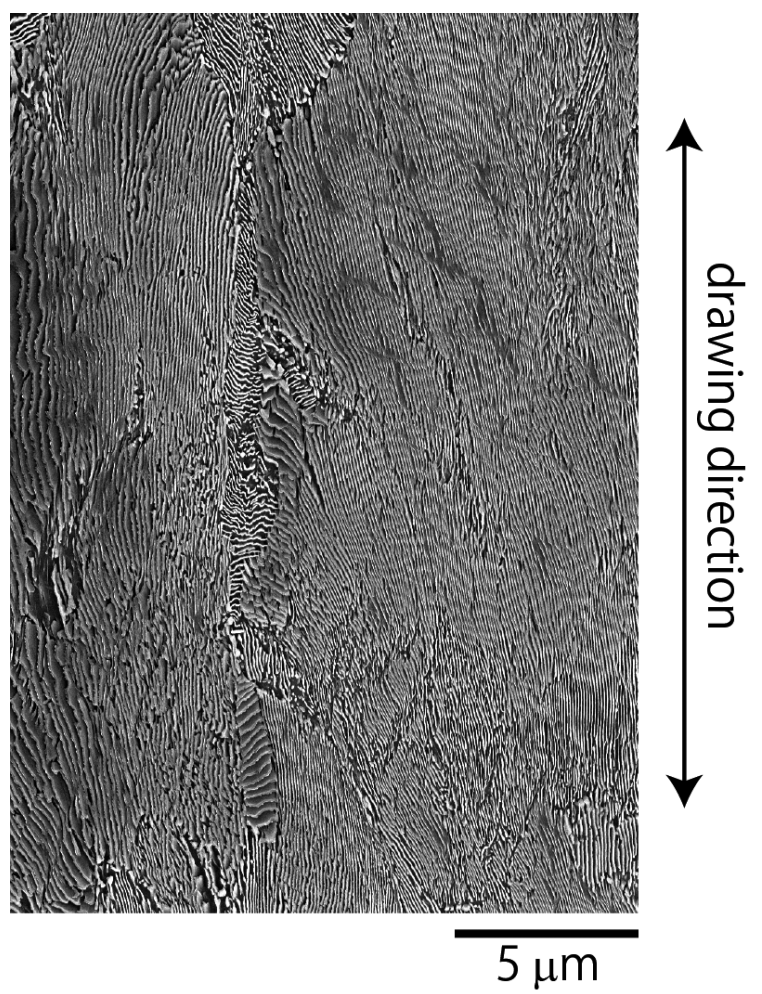

Fig. 1. SEM image of the L-cross section of the drawn wire used for the microbending test.

通り，パーライトコロニーに切欠きが内包される位置とし た。そして，HEに関する異方性を調査するため， $\alpha-\theta$ 界面 に対する向きが異なる MCLを 3 種類 (Type A-C) 用意した。 Fig.2 (c) に, 各 MCLの $\alpha-\theta$ 界面と切欠きとの方位関係を示 す。 $\alpha-\theta$ 界面と切欠きは, Type Aの MCLでは平行, Type B, CのMCLでは垂直とした。Type AとBのMCLは伸線軸と 垂直な断面 (T断面) に, Type Cの MCL は L 断面に加工し た。 $\mathrm{T}$ 断面では， $\alpha-\theta$ 界面は表面に対し概ね垂直を向いてい る (Fig.1)。このため, Type Cの MCL は, T断面には加工で きないことに注意する。

Fig.3に微小曲げ試験の実験配置を模式的に示す。文 献 ${ }^{12)}$ に記載の方法と同じく, 大気下または電解水素チャー ジ下で，MCLの自由端の近くにダイヤモンド製の conospherical圧子 (開き角 $60^{\circ}$, 先端曲率半径 $1 \mu \mathrm{m}$ 以下) を押込 んだ。圧子押込みは変位制御とし，押込み時間と最大変位 はそれぞれ $180 \mathrm{~s} ， 3000 \mathrm{~nm}$ とした。圧子押込みと並行して， 圧子の荷重一変位関係を記録した。

電解水素チャージは対極に白金を用いて電流制御で行っ た。陰極電流密度は $8.0 \mathrm{~A} / \mathrm{m}^{2}$ とし，電解液には触媒毒とし て $3 \mathrm{~g} / \mathrm{L}$ の NH4SCN を添加した $\mathrm{pH} 8.62$ のほう酸緩衝液を用 いた。MCLに水素を飽和させるため, 最初の微小曲げ試験 を実施する前に, $8.0 \mathrm{~A} / \mathrm{m}^{2}$ の陰極電流密度で水素を $1200 \mathrm{~s}$ 以上プレチャージした。EC-NI装置の原子間力顕微鏡機能 で電解水素チャージ下の表面凹凸を測定し，チャージによ り腐食が発生しないことも確認した。

Table 1. Chemical composition of the sample. The unit is mass $\%$.

\begin{tabular}{cccccc}
\hline $\mathrm{C}$ & $\mathrm{Si}$ & $\mathrm{Mn}$ & $\mathrm{P}$ & $\mathrm{S}$ & $\mathrm{Fe}$ \\
\hline 0.94 & 0.23 & 0.70 & 0.010 & 0.004 & bal. \\
\hline
\end{tabular}

(a)

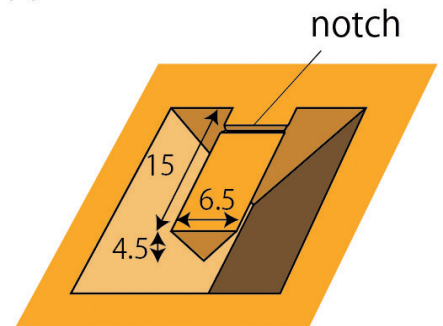

(c)

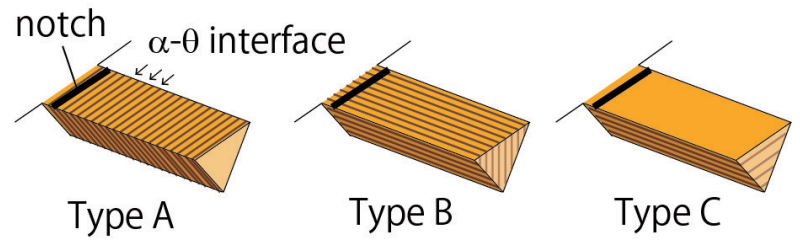

Fig. 2. (a) Shape and (b) location of the MCL fabricated for the microbending test. Schematics of the notch orientation in the types A-C MCLs are shown in (c). (Online version in color.) 
微小曲げ試験後, エタノールと約 $350 \mathrm{~K}$ の超純水で交互 に洗浄し，直ちに不活性ガスで乾燥させて，MCLに付着し た電解液を除去した。その後, MCLをSEM およびSTEM で観察し，き裂伝播経路を調査した。これらの観察方法の 詳細は $3 \cdot 4$ 節で改めて述べる。

MCL内の吸蔵水素量を調査するため, 昇温脱離分析 （TDA）も実施した。TDAには直径 $4 \mathrm{~mm}$, 長さ $14 \mathrm{~mm}$ の円 柱状の試験片を用いた。分析前に, 試験片はエメリー紙で 研磨し, 上記の微小曲げ試験と同じ条件 (陰極電流密度, 電解液) で $1.73 \mathrm{ks}$ (48 時間) 水素をチャージした。真空中

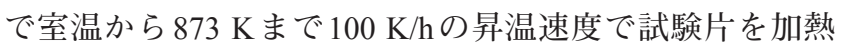
し, 試験片からの脱離水素を四重極型質量分析器により計 量した。

\section{3. 結果}

\section{$3 \cdot 1$ TDA}

Fig.4に測定された水素チャージ材のTDA曲線を示

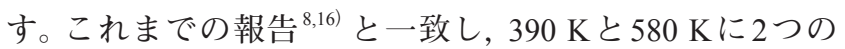

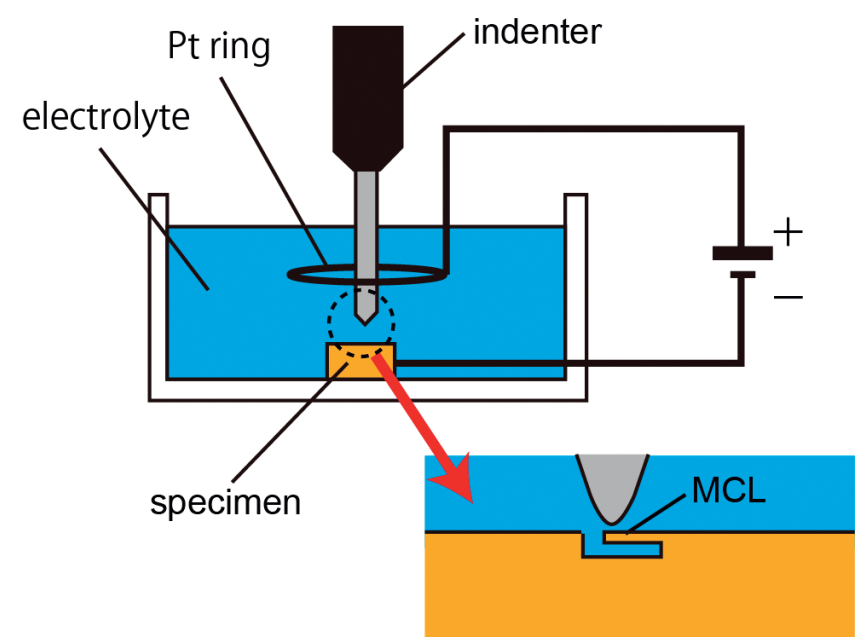

Fig. 3. Experimental setup of the microbending test. (Online version in color.)

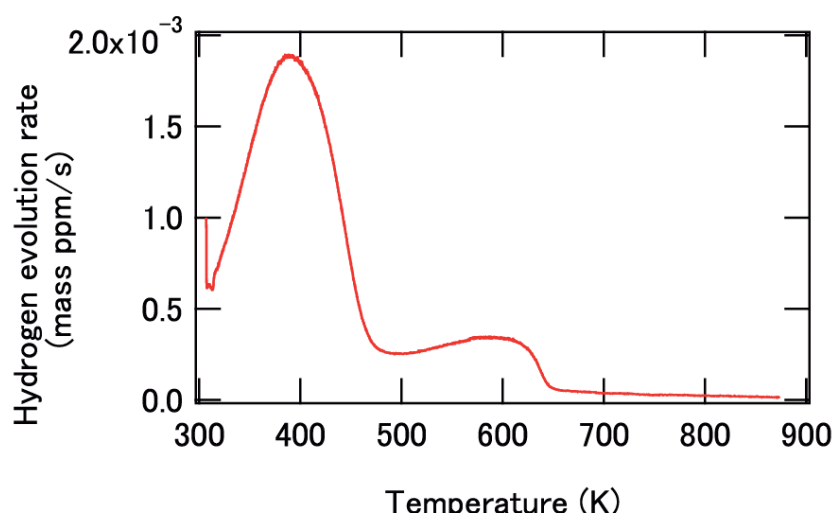

Fig. 4. TDA curve of the drawn wire, where hydrogen was charged for 48 hours in the same condition as for the microbending test. (Online version in color.)
水素放出ピークが認められた。TDA曲線から, 全水素量

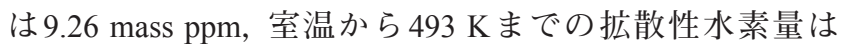
7.60 mass ppm と見積もられた。ここで, $493 \mathrm{~K} は 2 つ の$ 水素 放出ピークの谷底の温度である。このように, 実験方法に 記載の電解水素チャージ条件で, 微小曲げ試験中に, MCL に水素がチャージされることが確認された。

\section{$3 \cdot 2 \mathrm{MCL}$ のIB 加工}

試験結果の再現性を確認するため, Type A, B, Cの MCL は，それぞれ8個，8個，12個，FIB加工した。以降，便宜上， これらの MCL 「MCL A1-A8」,「MCL B1-B8」,「MCL C1C12」と呼ぶことにする。Fig.5に微小曲げ試験前に取得し た MCLのSEM像を示す。FIBの $\mathrm{Ga}^{+}$イオンビームで表面 がエッチングされ, SEM像にはラメラ組織が縞模様として 観察された。各MCLはこの縞模様を目印にFIB加工した。 $\mathrm{L}$ 断面において $\alpha-\theta$ 界面が表面と完全に平行なパーライト コロニーを探し出すことは, 確率論的に困難である。この ため, Type CのMCLについては, 縞の間隔 (ラメラ間隔) が極力広く, 表面と $\alpha-\theta$ 界面が概ね平行なパーライトコロ ニーを加工位置とした。

Table 2 にSEM像から計測された各MCLの寸法をまと める。また, Fig.6に Table 2の変数の定義を模式的に示す。 Table 2 には，微小曲げ試験後にMCLに形成された圧子痕 からもとめた荷重点と, 次式から計算した断面二次モーメ ントIも併せて記載する ${ }^{17)}$ 。

$$
I=\frac{a b^{3}}{36}
$$

平滑な MCLの場合, 線形弾性論では, 曲げ荷重 $P$ とたわみ $\delta$ には次の関係が成り立つ ${ }^{17)}$ 。

$$
P=\frac{3 E I}{L_{1}^{3}} \delta
$$
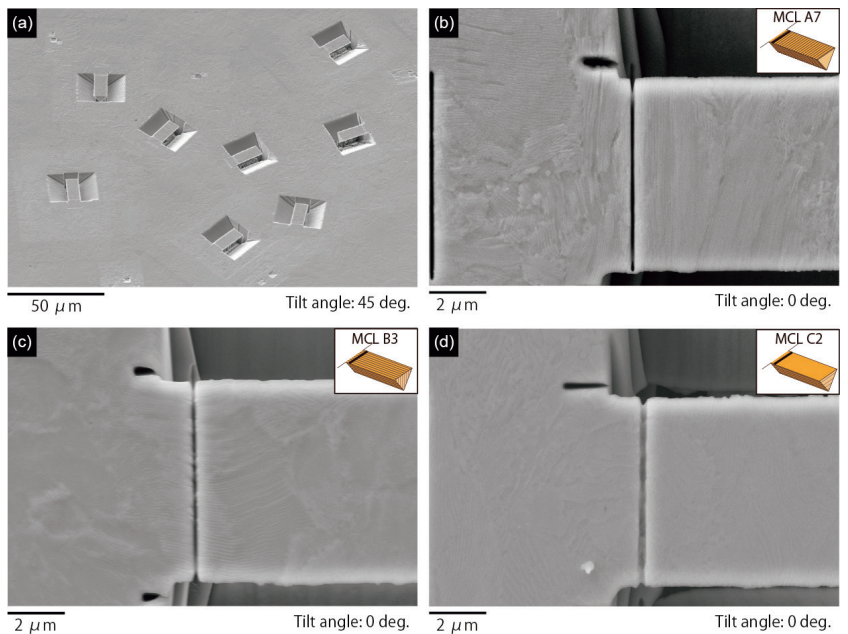

Fig. 5. SEM image of (a) the MCLs on the T cross-section, and those of the notch part of (b) the type-A, (c) type-B, and (d) type-C MCLs. (Online version in color.) 
ここで,Eはヤング率である。このように $P$ は $I$ に比例し て大きくなり，IはMCLの形状・寸法的な曲げ易さを表す。 Type AとBのMCLについては，寸法は概ね等しく，Iはい ずれの MCLも約 $15 \mu \mathrm{m}^{4}$ だった。一方, Type Cの MCLにつ いては，MCL C7 とC8のように， Iが $10 \mu \mathrm{m}^{4}$ 以下の形状 · 寸法的に曲がり易いMCLも含まれることが分かった。

Table 2. Dimension of fabricated MCLs measured from the SEM images.

\begin{tabular}{|c|c|c|c|c|c|c|c|c|}
\hline Type & Mark & $\begin{array}{c}a \\
(\mu \mathrm{m})\end{array}$ & $\begin{array}{c}b \\
(\mu \mathrm{m})\end{array}$ & $\begin{array}{c}L \\
(\mu \mathrm{m})\end{array}$ & $\begin{array}{c}L_{1} \\
(\mu \mathrm{m})\end{array}$ & $\begin{array}{c}L_{2} \\
(\mu \mathrm{m})\end{array}$ & $\begin{array}{c}I \\
\left(\mu \mathrm{m}^{4}\right)\end{array}$ & environment \\
\hline \multirow{8}{*}{ Type A } & $\mathrm{A} 1$ & 6.7 & 4.4 & 14.9 & 13.0 & 1.6 & 15.8 & \multirow{3}{*}{ Air } \\
\hline & $\mathrm{A} 2$ & 6.5 & 4.2 & 15.6 & 14.5 & 0.7 & 13.3 & \\
\hline & A3 & 6.4 & 4.2 & 14.8 & 13.4 & 0.8 & 12.8 & \\
\hline & A4 & 6.7 & 4.2 & 15.1 & 13.7 & 1.0 & 13.8 & \multirow{5}{*}{ Hydrogen } \\
\hline & A5 & 6.7 & 4.4 & 14.8 & 13.4 & 0.5 & 16.3 & \\
\hline & A6 & 6.8 & 4.6 & 14.3 & 13.4 & 0.5 & 18.8 & \\
\hline & A7 & 6.6 & 4.4 & 14.9 & 13.7 & 0.6 & 15.6 & \\
\hline & A8 & 7.0 & 4.5 & 15.3 & 12.6 & 0.6 & 18.2 & \\
\hline \multirow{8}{*}{ Type B } & B1 & 6.7 & 4.6 & 14.9 & 12.6 & 1.1 & 18.5 & \multirow{4}{*}{ Air } \\
\hline & B2 & 6.8 & 4.4 & 14.9 & 13.7 & 1.2 & 16.1 & \\
\hline & B3 & 6.9 & 4.4 & 15.1 & 13.1 & 1.0 & 16.7 & \\
\hline & B4 & 7.1 & 4.3 & 15.7 & 13.4 & 0.9 & 15.8 & \\
\hline & B5 & 6.8 & 4.2 & 14.9 & 13.5 & 0.8 & 14.5 & \multirow{4}{*}{ Hydrogen } \\
\hline & B6 & 6.8 & 4.4 & 15.0 & 13.0 & 0.8 & 15.7 & \\
\hline & B7 & 6.7 & 4.2 & 15.0 & 12.9 & 0.9 & 13.8 & \\
\hline & B8 & 6.6 & 4.2 & 15.5 & 14.2 & 0.7 & 13.7 & \\
\hline \multirow{12}{*}{ Type C } & $\mathrm{C} 1$ & 6.6 & 3.6 & 15.8 & 13.4 & 1.0 & 8.3 & \multirow{6}{*}{ Air } \\
\hline & $\mathrm{C} 2$ & 6.5 & 3.7 & 15.8 & 13.5 & 1.1 & 9.1 & \\
\hline & $\mathrm{C} 3$ & 6.4 & 3.6 & 15.4 & 13.2 & 0.6 & 8.4 & \\
\hline & $\mathrm{C} 4$ & 6.8 & 4.3 & 15.3 & 15.3 & 0.7 & 14.8 & \\
\hline & $\mathrm{C} 5$ & 6.7 & 4.1 & 15.8 & 15.8 & 0.8 & 13.1 & \\
\hline & $\mathrm{C} 6$ & 6.5 & 4.1 & 15.1 & 15.1 & 0.6 & 12.4 & \\
\hline & $\mathrm{C} 7$ & 6.4 & 3.7 & 14.8 & 13.0 & 1.1 & 9.2 & \multirow{6}{*}{ Hydrogen } \\
\hline & $\mathrm{C} 8$ & 6.2 & 3.4 & 14.8 & 13.2 & 0.8 & 6.9 & \\
\hline & $\mathrm{C} 9$ & 6.8 & 4.4 & 15.1 & 15.1 & 0.6 & 15.7 & \\
\hline & $\mathrm{C} 10$ & 6.6 & 4.3 & 14.2 & 14.2 & 0.6 & 14.3 & \\
\hline & $\mathrm{C} 11$ & 6.7 & 4.2 & 15.8 & 15.8 & 0.8 & 13.4 & \\
\hline & $\mathrm{C} 12$ & 6.4 & 4.1 & 15.2 & 15.2 & 0.5 & 12.5 & \\
\hline
\end{tabular}

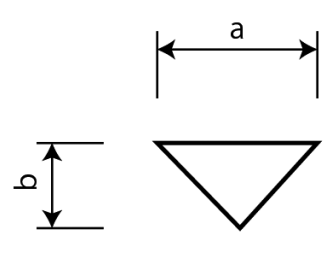

front view

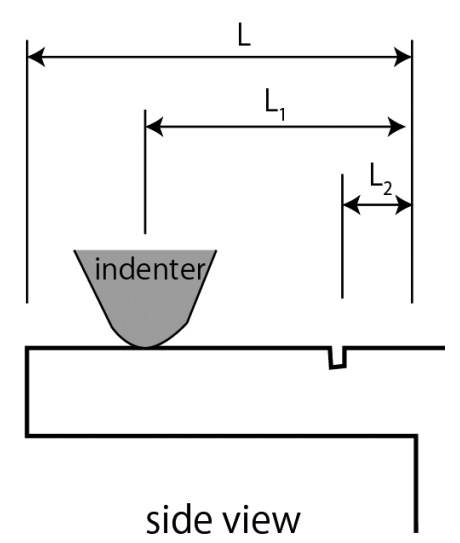

side view
Fig. 6. Definition of parameters in Table 2.

\section{$3 \cdot 3$ 微小曲げ試験}

MCL A1-A3，MCL B1-B3，およびMCL C1-C6は大気下 で，MCL A4-A6，MCL B4-B8，およびMCL C7-C12 は電解 水素チャージ下で微小曲げ試験を実施した。Fig.7 に曲げ

(a)

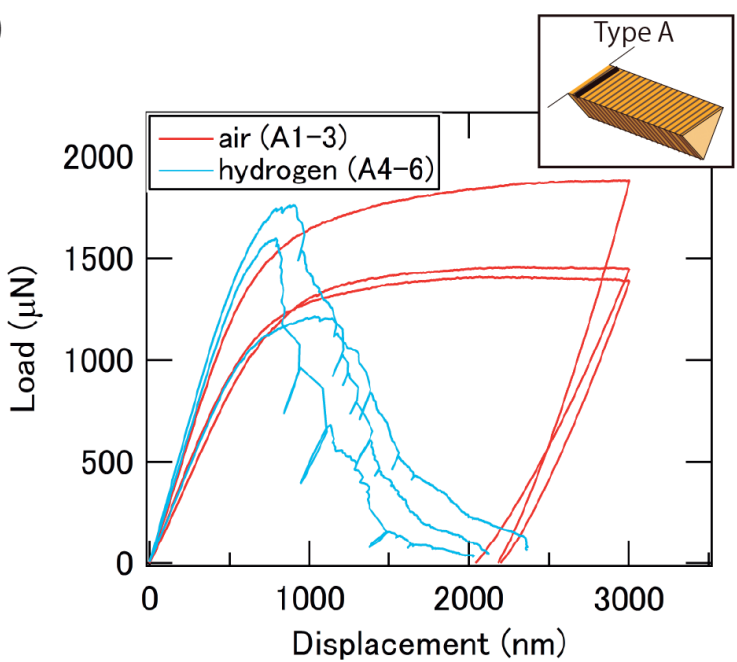

(b)

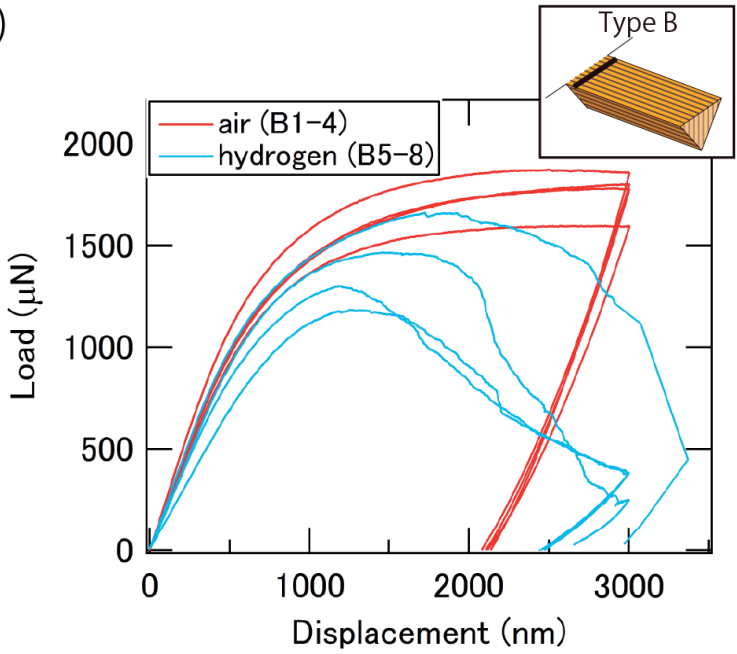

(c)

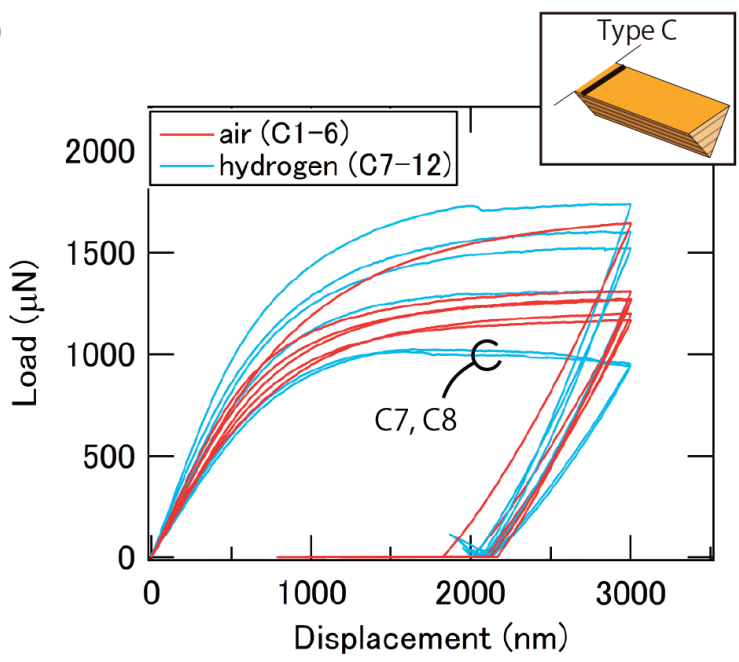

Fig. 7. Load-displacement relations recorded during the microbending test of (a) the type-A, (b) type-B, and (c) type-C MCLs. (Online version in color.) 
変形中に記録された圧子の荷重一変位関係を示す。また, Figs.8-10 に曲げ変形後の Type A-Cの MCLのSEM像をそれ ぞれ示す。大気下では，切欠きの向きによらず，変位の増 加で荷重は単調増加し，き裂は認められなかった。なお， MCLによる最大荷重のばらつきの主な原因は, MCLの寸 法のばらつきにある。最大荷重はIの值が大きな MCLほ ど大きくなる傾向があった。一方，電解水素チャージ下で は，切欠きの向きによって試験結果に大きな差異が認め られた。Type AのMCLでは，荷重は塑性変形領域で急低 下し，最大変位の $3000 \mathrm{~nm}$ に到る前に概ねゼロとなった。 SEM像には, MCLの切欠き底に, MCLをほぼ貫通する深 いき裂が観察された（Fig.8）。Type Bの MCLでも Type Aの MCL と同様に荷重が低下し，切欠き底にき裂が観察され た（Fig.9）。しかし，Type AのMCLに比べて，変位に対する
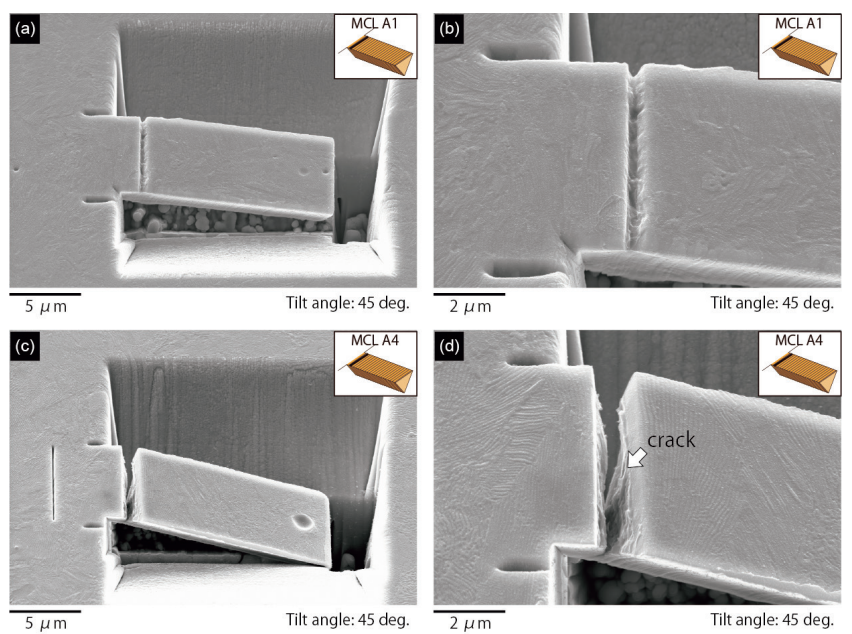

Fig. 8. SEM images of the type-A MCLs bent $(a, b)$ in air and (c, d) during the cathodic hydrogen charging. The images in (b) and (d) are magnified images of the notch parts in (a) and (c), respectively. (Online version in color.)
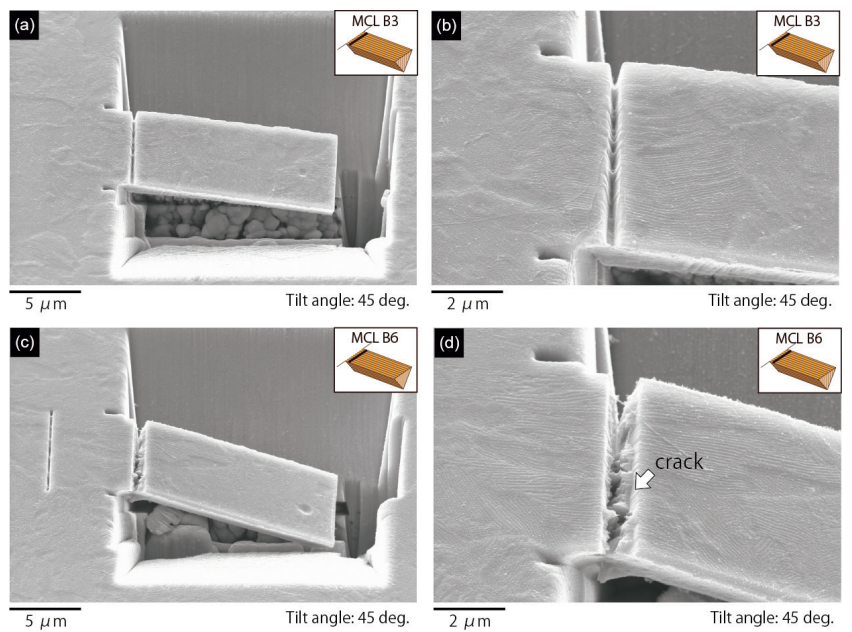

Fig. 9. SEM images of the type-B MCLs bent $(a, b)$ in air and (c, d) during the cathodic hydrogen charging. The images in (b) and (d) are magnified images of the notch parts in (a) and (c), respectively. (Online version in color.)
荷重低下の程度は小さく, き裂は浅かった。Type Cの MCL では, Iの值が小さな MCL C7 と C8 でのみ荷重が低下し, き裂が観察された（Fig.10）。これらのMCLは, Type A, B の MCL と比べて，さらに荷重低下は小さく，き裂は浅かっ た。き裂はMCLの厚さ方向だけでなく, 幅方向にも貫通し ていなかった。その他のIの值が大きな MCL C9-C12では， 荷重低下やき裂は認められなかった。

MCLの断面積が減少すると, 荷重一変位関係において荷 重が低下することが知られている ${ }^{12,18,19)}$ 。即ち, 荷重低下が 大きいほど, 所定の歪みを与えた際にき裂がより伝播し易 いと言える。このように, 上記の MCLによる微小曲げ試験 結果の差異から, HEき裂は $\alpha-\theta$ 界面と垂直な方向より平行 な方向に伝播し易いことが分かった。

Fig.11に, Type AとBのMCLのき裂面のSEM像を示す。 なお，Type CのMCLはき裂開口が小さく，き裂面を観察で きなかった。Type AのMCLのき裂面は比較的平坦で，き裂 面には波状の段差が観察された。一方，Type BのMCLのき 裂面には約 $160 \mathrm{~nm}$ の間隔で縞状に凹凸が観察され, 微小曲 げ試験時にデラミネーション破壊が発生していることが示 唆された。

\section{4 SEM, TEM 観察}

HEき裂の伝播経路を確認するため, Type AとCの MCL をFig.12に示す形状にFIB加工し, MCLの幅方向に対して
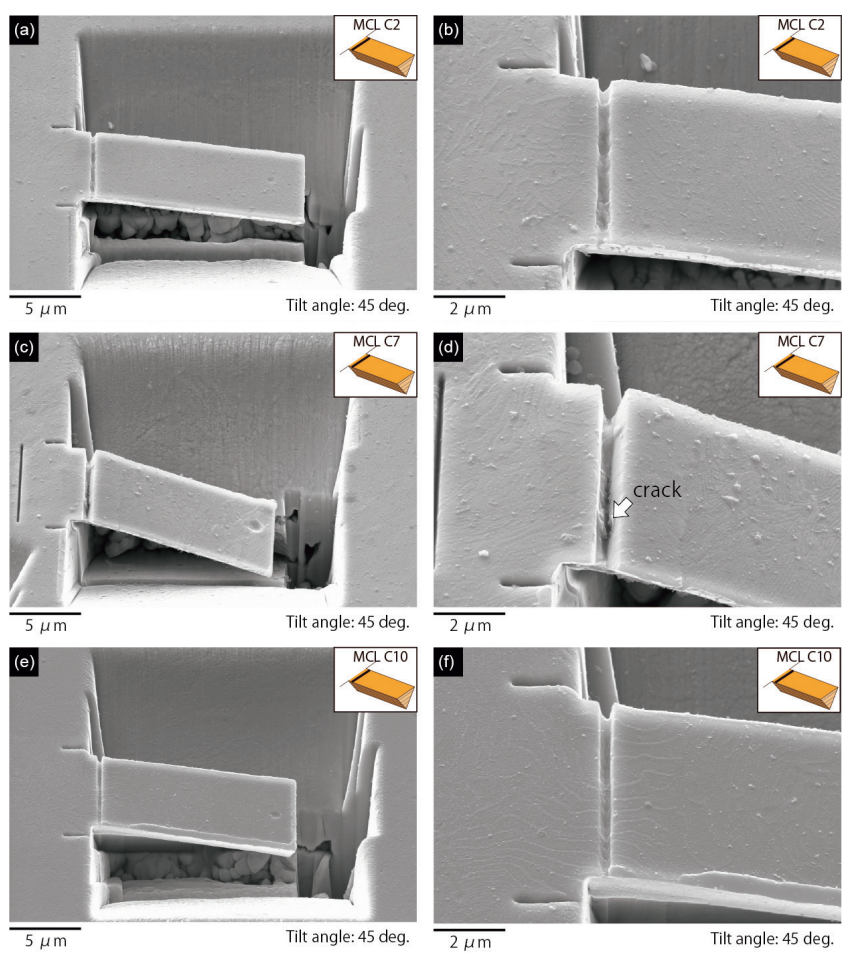

Fig. 10. SEM images of the type-C MCLs bent $(a, b)$ in air and (c-f) during the cathodic hydrogen charging. The SEM images in (c, d) are of the MCL C7 with small $I$, and those in (e, f) are of the MCL C10 with large $I$. The images in (b), (d) and (f) are magnified images of the notch parts in (a), (c), and (e), respectively. (Online version in color.) 
垂直な断面をSEM観察した。FIBの $\mathrm{Ga}^{+}$イオンによるき裂 の損傷を防ぐため, FIB加工前に切欠き底にはPtの保護層 をFIB蒝着した。3·3節で述べた通り, Type AのMCLでは, 最大変位の $3000 \mathrm{~nm}$ まで圧子を押込むとき裂はMCLをほ ぼ貫通した。一方，き裂伝播経路をSEMで特定するには， 停留き裂を観察することが不可欠である。このため, Type Aの MCLについては, Fig.13に荷重一変位曲線を示すよう に, 変位 $1000 \mathrm{~nm} に$ に打る荷重低下の発生直後に微小曲げ 試験を中断し，停留き裂の作製を図ったMCL（MCL A7） をSEM観察した。Type CのMCLについては, 最大変位 $3000 \mathrm{~nm}$ の微小曲げ試験後に停留き裂が認められた MCL （MCL C8）をSEM観察した。Fig.14に取得された断面の SEM像を示す。期待通り，MCL A7には停留き裂が作製さ れていた。Type AのMCLでは鋭いき裂が $\alpha-\theta$ 界面近くに観 察された。一方, Type CのMCLでは先端が鈍化したき裂が 観察された。圧子押込み深さはType Aの MCLはType Cの MCL3 分の1であるが，き裂長さは両者で概ね等しかった。

空間分解能が十分でないため, Fig.14のSEM像からは, Type Aの MCL の HEき裂の伝播経路が $\alpha-\theta$ 界面，ラメラ $\theta$ 内， $\alpha-\theta$ 界面近くのラメラ $\alpha$ 内, のいずれか判別することは 困難である。これを明確化するため，次に，STEM観察を 行った。STEM観察の試験片には, MCL A7 と同様, 微小曲 げ試験を中断して停留き裂を作製したMCL A8を用いた (Fig.13)。Fig.15にSTEM用の試験片の作製手順を模式的に
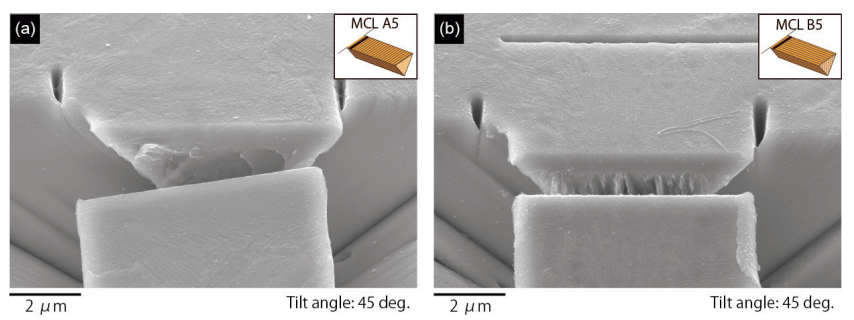

Fig. 11. SEM images of the crack surfaces of (a) the type-A and -B MCLs bent during the cathodic hydrogen charging. (Online version in color.)

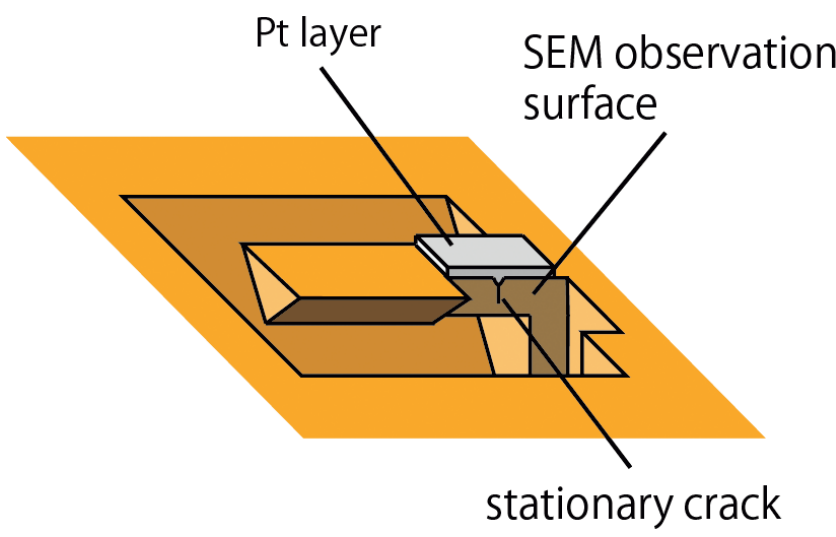

Fig. 12. FIB milling of the cross-section for the SEM observations of the stationary crack. (Online version in color.)
示す。FIBによる lift-out法 ${ }^{20)}$ で表面から MCLを摘出し，こ れをFIBと Arミリングを用いて薄片化して試験片を得た。

Fig.16 (a) とFig.16 (b) に, 取得された低倍率および高 倍率の明視野STEM像をそれぞれ示す（紙面の制約上，低 倍率像は高倍率像に対して時計回りに90度回転させてい る)。図中に扔いて破線で囲ったラメラ $\theta$ は, 暗視野像と電 子線回折パターンからその位置を決定した。HEき裂は $\alpha-\theta$ 界面付近を伝播して打り,ラメラ $\theta$ の終端部で停止してい た。Fig.16 (c) に, Fig.16 (b) の矩形領域に対応するTEMの 格子像を示す。き裂内部にはFIB加工時の再付着により形 成されたアモルファス構造が, き裂直下 $2-3 \mathrm{~nm}$ の領域には

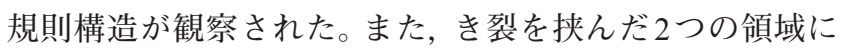
同じ相は存在せず，必ず，き裂の片側には $\theta$ 相，もう片側に は $\alpha$ 相が観察された。

ラメラ $\theta$ 内の結晶方位分布もHEき裂伝播に影響を与え ると予想される。このため, $\theta$ の暗視野TEM像も測定した。 Fig.17に取得された暗視野TEM像を示す。破線で示したラ メラ $\theta$ 内部の電子線強度は不均一であり, $\theta$ の断片化が認 められた。文献 ${ }^{5,6)} に$ 報告されているようなナノ微細粒が, 本研究の冷間伸線条件でも形成されていることが分かっ た。

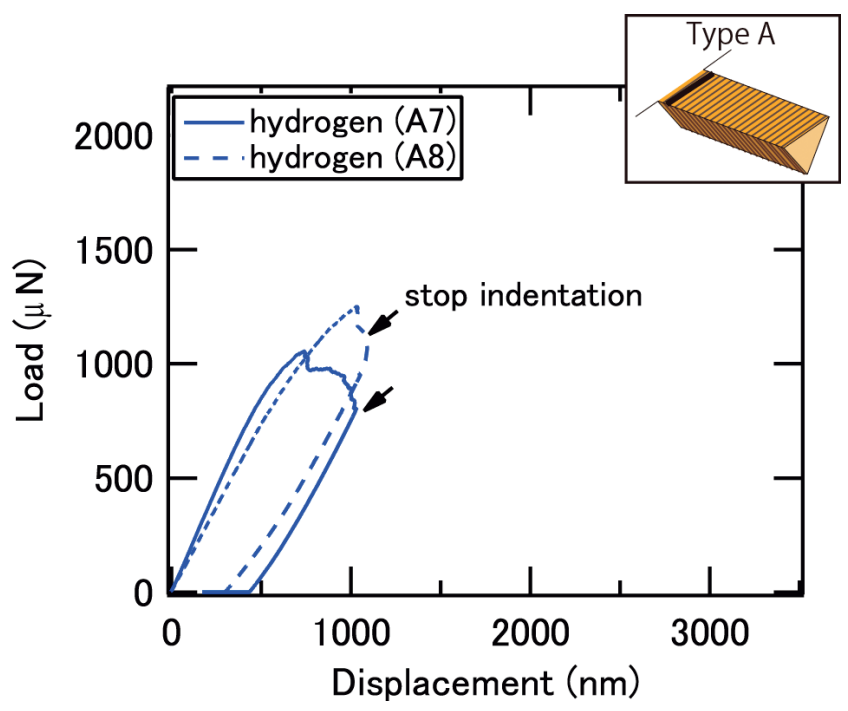

Fig. 13. Load-displacement relations of the type-A MCLs used for the SEM and STEM observations of the stationary crack. (Online version in color.)
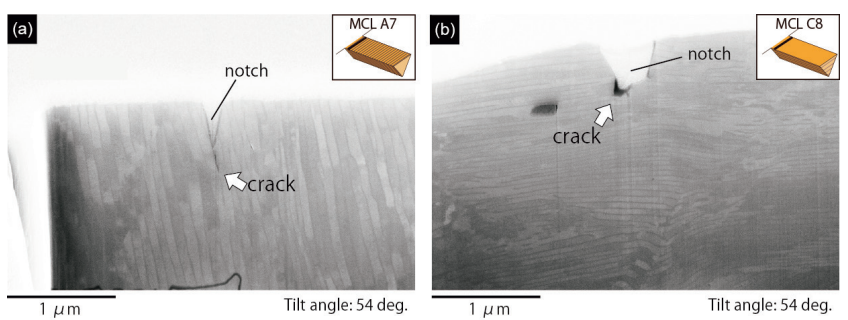

Fig. 14. SEM images of the cross-sections of (a) the type-A and (b) type-C MCLs bent during the cathodic hydrogen charging. (Online version in color.) 


\section{4. 考察}

\section{$4 \cdot 1$ ヤング率と流動応力に及ぼす水素の影響}

文献 ${ }^{12)}$ に記載の通り, 微小曲げ試験の荷重一変位関係か ら $E$ と MCLの厚さ方向の平均流動応力 $\bar{c}$ を推定できる。即

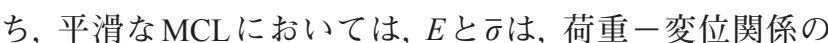
弾性変形領域の勾配 $g$ と塑性変形領域の荷重 $P_{\text {plastic }}$ を用い て次式より計算できる。

$$
\begin{aligned}
& g=\frac{3 I}{L_{1}^{3}} E=\frac{a b^{3}}{12 L_{1}^{3}} E . \\
& \bar{\sigma}=\frac{81}{8} \frac{P_{\text {plastic }} L_{1}}{a b^{2}}
\end{aligned}
$$

FIB加工した MCLが切欠きを持たないと仮定し, Fig.7の 荷重一変位関係およびTable 2の実際のMCLの寸法からE とあを計算し, これらの基本的な機械的性質に及ぼす水素 の影響を調査した。

Table 3 に計算された $E$ と市の值を, $g$ と $P_{\text {plastic }}$ の值とと もに示す。式 (4) はMCLの固定端におけるモーメントの
釣り合いから演繹され ${ }^{21)}$, 最大変位では固定端は完全に 塑性変形していると予想される。このため, 変位 $3000 \mathrm{~nm}$ における荷重を $P_{\text {plastic }}$ に代入した。また, $P_{\text {plastic }}$ はき裂が発 生し，荷重が低下したMCLについては正確に決定できな い。このため，き裂が発生しなかったType CのMCLにつ いてのみ計算結果を記載した。大気下では, $E$ と宁の值はそ れぞれ $121.5 \pm 16.7 \mathrm{GPa}, 1832 \pm 260 \mathrm{MPa}$ であった。一方， 電解水素チャージ下では，Eと元の值はそれぞれ $108.3 \pm$ $18.3 \mathrm{GPa}, 1731 \pm 115 \mathrm{MPa}$ であった。実際の MCL は切欠き を有しており，計算された $E$ と岢の絶対值は信頼性が低い。 しかし，上記の計算結果から $E$ と $\bar{\sigma} へ$ 水素の影響は小さ いと言える。一般に, $\bar{\sigma}$ は転位運動 (転位易動度, 転位間相 互作用，等）と深く関係している。伸線パーライト鋼につ いては，水素が転位運動に与える影響は小さいと推察され る。

\section{4・2 HEき裂の優先伝播経路}

装置構造上，微小曲げ試験後に試料をEC-NI装置から外 す際の数分間, 試料はアルカリ性の電解液 $(\mathrm{pH}$ 8.6) に自 然浸漬された状態になる。一方, Syugaevらは, メカニカル アロイング法で作製したバルク $\theta$ を電気化学測定し, $\alpha$ と

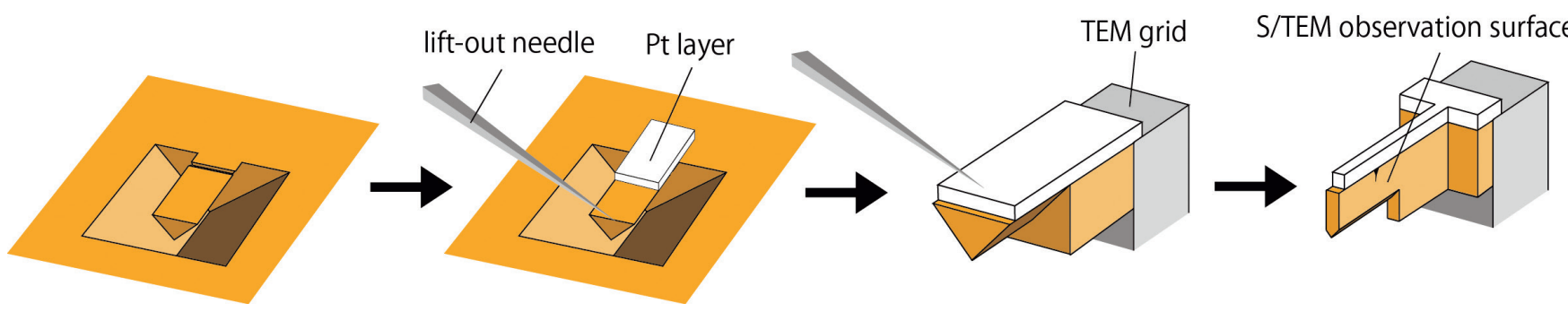

Fig. 15. Milling procedure of the MCL into the STEM specimen. (Online version in color.)
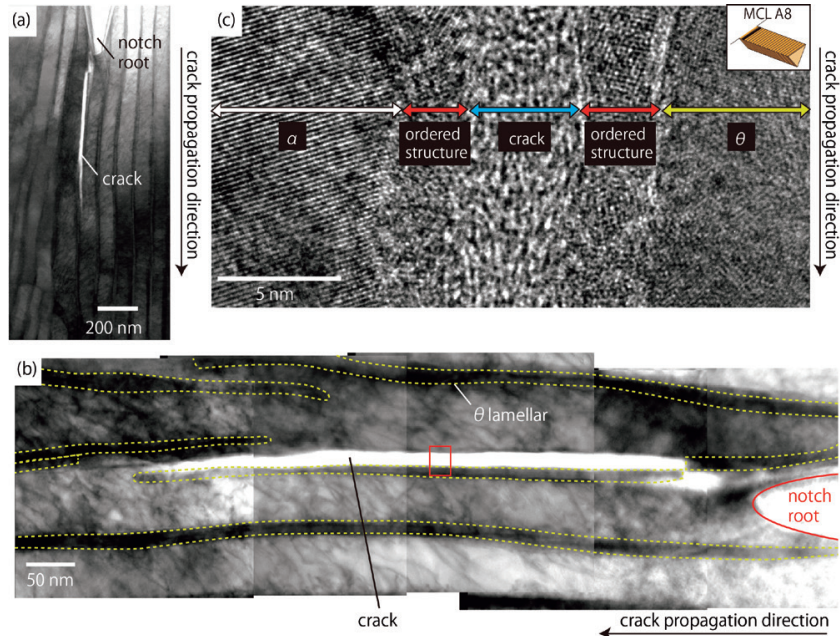

Fig. 16. (a) low- and (b) high-magnification bright-field STEM images of the stationary crack in the type-A MCL. The high-magnification image in (b) was rotated by 90 degree in the clockwise direction due to space limitation. The image in (c) is a lattice image obtained by high resolution TEM corresponding to the area indicated by the rectangle in (b). (Online version in color.)

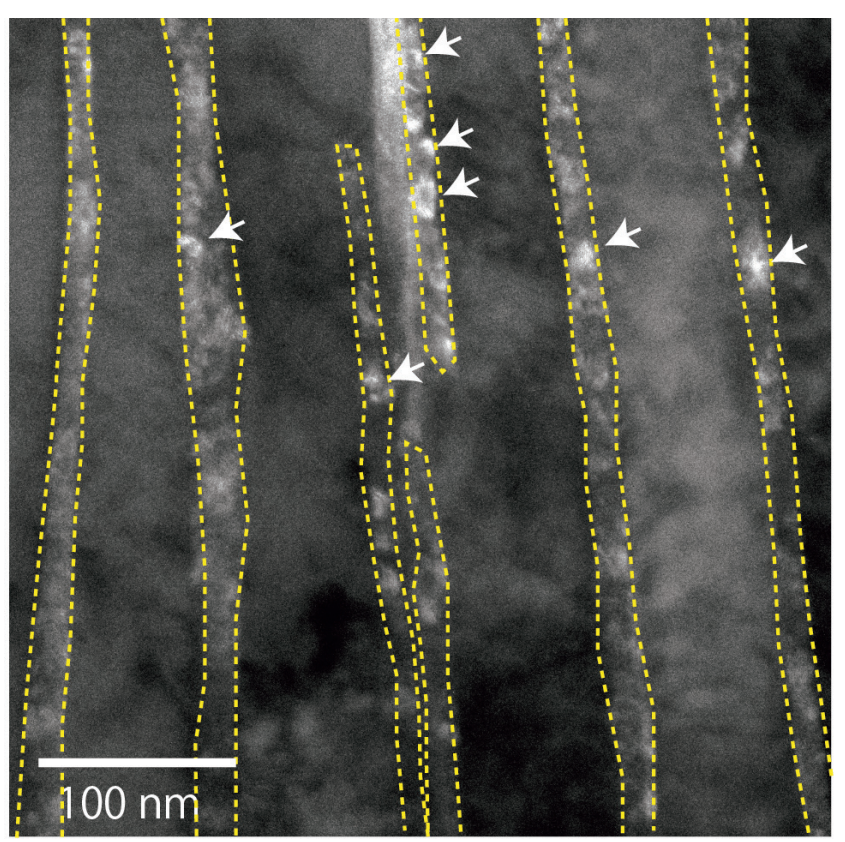

Fig. 17. Dark-field TEM image of $\theta$. (online version in color.) 
同様に,アノード分極で $\mathrm{Fe}_{3} \mathrm{O}_{4}$ と $\gamma-\mathrm{Fe}_{2} \mathrm{O}_{3}$ の二層からなる不 動態皮膜が形成されること, $\mathrm{pH}$ の増加で不動態電位は低 下すること，を報告している ${ }^{22,23)}$ 。したがって，TEMの格 子像 (Fig.16 (c)) に打いて観察されたき裂表面直下の規則 構造は, HEき裂伝播後に電解液によってラメラ $\alpha$, ラメラ $\theta$ それぞれの表面に形成された自己不動態皮膜と考えられ る。ナノスケールで $\alpha-\theta$ 界面近くをき裂が伝播しているこ と $($ Fig.16 (c) ) , ラメラ $\theta$ 終端部でのき裂が停止しているこ と (Fig.16 (b)) から, HEき裂の優先伝播経路は, ラメラ $\alpha$ やラメラ $\theta$ の内部ではなく,$\alpha-\theta$ 界面であると言える。

伸線パーライト鋼の $\alpha-\theta$ 界面は伸線加工による大量の 格子久陥のため整合性が低く，凝集力は低いはずである。 また，そのような非整合な界面は多くの水素をトラップ する。観察された $\alpha-\theta$ 界面の破壊は, 格子脆化 (Hydrogen Enhanced Decohesion : HEDE) 機構 ${ }^{24,25)}$, 即ち界面にトラッ プされた水素が界面の凝集力を低下させることにより生じ ている可能性がある。

$\theta$ の暗視野像から，ラメラ $\theta$ はナノ微細粒から形成され， 高密度で粒界が分布していることが分かった（Fig.17）。一 般に，このような粒界はき裂伝播の障害として働く。一方， Kawakami and Matsumiyaは第一原理計算で $\theta$ 内の水素卜 ラップサイトを探索し，室温では拡散障壁が高く， $\theta$ 内に 水素はほとんど侵入しないことを報告している ${ }^{26)}$ 。ラメラ $\theta$ 内にき裂が認められなかった原因は, 高密度の粒界と低 い水素濃度にあると考えられる。

\section{$4 \cdot 3$ 破壊䩲性値}

HEき裂が $\alpha-\theta$ 界面に沿ってどのくらい容易に伝播する のか定量的に評価するため, 停留き裂を形成したType Aの MCL（MCL A7）に関して破壊勒性值 $K_{c}$ を計算した。

き裂長さ $x$ と曲げ荷重 $P$ から決まる応力拡大係数 $K$ が, $K_{c}$ と等しくなるように，き裂はMCL内を伝播する。観察さ れた $\alpha-\theta$ 界面のHEき裂は鋭く，刃状き裂に近似できる。そ のような刃状き裂を持つ三角形断面の片持ち梁では, $x \ll b$ の場合，モードIの $K$ は次式で与えられる ${ }^{18)} 。$

$$
K=\frac{12 P L_{3}}{a b^{2}} \times 1.12 \sqrt{\pi x}
$$

ここで, $L_{3}$ は荷重点とき裂との距離である。Fig.13の荷重 一変位関係と Fig.14 (a) の断面のSEM像からPが750 $\mu \mathrm{N}$ のとき, $x$ は $0.83 \mu \mathrm{m}$ であることが分かる。一方, Table 2 に まとめた通り, MCL A7では, $a, b, L_{3}\left(=L_{1}-L_{2}\right)$ はそれ ぞれ $6.6 \mu \mathrm{m}, 4.4 \mu \mathrm{m}, 13.1 \mu \mathrm{m}$ であった。よって, 式 (5) か ら $K_{c}$ は $1.7 \mathrm{MPa} \mathrm{m}{ }^{1 / 2}$ と見積もられる。実際はMCLの幅方向 にxの值は異なる可能性がある。このため, 上記の $K_{c}$ の值 の精度は検討の余地はあるが, 桁数については実際と合っ ていると考えてよい。

なお，式 (5) のPにき裂発生荷重 ( 荷重一変位 曲線に打いて荷重低下が発生した荷重）を，xに FIB加工した切欠きの深さを代入して， $K_{c}$ を見積 もることも可能のように思われる。しかし，こ のような解析は不適切であることを注意してお く。切欠き底はFIBの $\mathrm{Ga}^{+}$イオンにより加工硬化しており, き裂が発生しにくくなっている。さらに, 切欠き底の曲率 は有限であり, 式 (4) では $K_{c}$ を過大評価してしまう。上記 の通り，停留き裂から $K_{c}$ を見積もった方が精度の良い結果 を得られる。また, Type Cの MCLについては, 容易に $K_{c} を$ 見積もれないことも注意しておく。式 (4) は, 塑性変形領 域がき裂先端部に局在化しており, 小規模降伏条件を満足 する場合に適用できる。Type Aの MCLでは, わずかな変位 の圧子押込みで塑性変形開始直後に鋭いき裂が形成された (Fig.14 (a))。一方, Type Cの MCLでは, 大きな変位の圧子 押込みで，先端が鈍化したき裂が形成された（Fig.14（b)）。 このため, 小規模降伏条件はType Aの MCLでは満足され ているが, Type CのMCLは満足されていない可能性が高 い。Type Cの MCLの破壊勒性は, 塑性変形を考慮した J 積 分による評価が必要であり, これについては今後の課題で ある。

マクロスケールの破壊勒性試験により, 水素チャージ した焼き戻しマルテンサイト鋼の $K_{c}$ は, 約 $20 \mathrm{MPa} \mathrm{m}^{1 / 2}$ と 測定されている ${ }^{27)}$ 。一方，水素チャージした伸線パーラ

Table 3. $E$ and $\bar{\sigma}$ calculated from the observed load-displacement relations in Fig.7 and the dimension of the MCLs in Table 1.

\begin{tabular}{|c|c|c|c|c|c|c|c|}
\hline Mark & $g(\mu \mathrm{N} / \mathrm{nm})$ & $P_{\text {plastic }}(\mu \mathrm{N})$ & $E(\mathrm{GPa})$ & $\bar{\sigma}(\mathrm{MPa})$ & Avg. $E(\mathrm{GPa})$ & Avg. $\bar{\sigma}(\mathrm{MPa})$ & Environment \\
\hline $\mathrm{C} 1$ & 1.35 & 1165 & 129.6 & 1883 & \multirow{6}{*}{$121.5 \pm 16.7$} & \multirow{6}{*}{$1832 \pm 260$} & \multirow{6}{*}{ Air } \\
\hline $\mathrm{C} 2$ & 1.36 & 1267 & 122.1 & 1952 & & & \\
\hline $\mathrm{C} 3$ & 1.51 & 1192 & 139.0 & 1916 & & & \\
\hline $\mathrm{C} 4$ & 1.57 & 1266 & 89.9 & 1408 & & & \\
\hline $\mathrm{C} 5$ & 1.51 & 1639 & 126.5 & 2162 & & & \\
\hline C6 & 1.72 & 1307 & 121.7 & 1673 & & & \\
\hline C9 & 2.10 & 1865 & 102.5 & 1658 & \multirow{4}{*}{$108.3 \pm 18.3$} & \multirow{4}{*}{$1731 \pm 115$} & \multirow{4}{*}{ Hydrogen } \\
\hline $\mathrm{C} 10$ & 1.79 & 1796 & 88.2 & 1888 & & & \\
\hline $\mathrm{C} 11$ & 1.71 & 1778 & 132.1 & 1745 & & & \\
\hline $\mathrm{C} 12$ & 1.60 & 1592 & 110.4 & 1632 & & & \\
\hline
\end{tabular}


イト鋼の $K_{c}$ は，伸線材動径方向のき裂伝播に関しては約 $40 \mathrm{MPa} \mathrm{m}^{1 / 2}$ と測定されている ${ }^{10)}$ 。よって，微小曲げ試験で 得られた $K_{c}$ の值 $\left(1.7 \mathrm{MPa} \mathrm{m}^{1 / 2}\right)$ は従来の值より一桁小さい。 一般に，巨視き裂の伝播は，多くの微視き裂の伝播の結果 として起こる ${ }^{28,29)}$ 。また，マクロスケールの試験では，き裂 はコロニー境界や旧 $\gamma$ 粒界と衝突して伝播するが，微小曲 げ試験ではき裂はこれらの境界と衝突して伝播しない。こ のようにき裂伝播の形態に差異があるため，マクロスケー ルとミクロスケールの破壊勒性試験では $K_{c}$ の值に大きな 差異があると考えられる。

\section{$4 \cdot 4$ 伸線パーライト鋼の優れた耐 HE 性の発現機構}

Type Aの MCLの微小曲げ試験結果は, 水素環境下で $\alpha-\theta$ 界面に対して垂直に引張応力が働くと， $\alpha-\theta$ 界面に沿って 長いき裂が発生することを意味している（Fig.14 (a))。一 方, Type B と CのMCLの微小曲げ試験の結果は, 水素環境 下で $\alpha-\theta$ 界面に対して平行に引張応力が働いてもき裂が発 生しない，あるいはき裂が発生しても，短くて先端が鈍化 したき裂になることを意味する（Fig.14（b)）。Fig.1に示し た通り，伸線パーライト鋼の $\alpha-\theta$ 界面は伸線軸と平行に配 向している ${ }^{3,4)}$ 。したがって，水素環境下で伸線パーライト 鋼に伸線軸方向に引張応力を負荷しても，き裂はほとんど 発生しない。伸線パーライト鋼の優れた耐 HE性は，その 異方的なミクロ組織によって発現していると結論付けられ る。

\section{5. まとめ}

伸線パーライト鋼の表面に $\alpha-\theta$ 界面に対する向きの異な る切欠き付 MCLを FIB 加工し, EC-NI装置を用いて大気下 と電解水素チャージ下で微小曲げ試験を実施した。その結 果，以下の知見が獲得された。

（1）Type A，B，Cの MCLの順で, 変位に対する荷重低下の 程度は大きく，発生した HEき裂は深かった。HEき裂 は， $\alpha-\theta$ 界面と垂直な方向より平行な方向に伝播しやす いことが見出された。

(2) MCL内の停留き裂をSEM観察およびSTEM観察し, $\alpha-\theta$ 界面が HEき裂の優先伝播経路であることを特定し た。

（3）測定された荷重－変位関係と MCLの実際の寸法から $E$ と市の值を計算した。これらの機械的性質は電解水素 チャージによって不変だった。
（4）微小曲げ試験の曲げ荷重とSEMで計測した対応する HEき裂の長さから， $\alpha-\theta$ 界面のき裂伝播に関して $K_{c}$ を 計算し, $1.7 \mathrm{MPa} \mathrm{m}^{1 / 2}$ と見積もられた。

（5）伸線パーライト鋼の異方的なミクロ組織が，伸線材動 径方向への HEき裂の伝播を抑制し，これにより伸線 方向の優れた耐HE性が発揮されていることが見出さ れた。

\section{文献}

1 ) B.Marandet: $N A C E, \mathbf{5}(1977), 774$.

2 ) T.Fujita and T.Yamada: $N A C E, \mathbf{5}(1977), 736$

3 ) J.D.Embury and R.M.Fisher: Acta Metall., 14(1966), 147.

4 ) V.K.Chandhok, A.Kasak and J.P.Hirth: Trans. Am. Soc. Met., 59(1966), 288

5 ) D.A.Porter, K.E.Easterling and G.D.W.Smith: Acta Metall., 26(1978), 1405

6 ) M.H.Hong, W.T.Reynolds, Jr., T.Tarui and K.Hono: Metall. Mater. Trans. A, 30(1999), 717

7 ) N.Sarafianos: J. Mater. Sci. Lett., 8(1989), 1486.

8 ) K.Takai, J.Seki and Y.Honma: Tetsu-to-Hagané, 81(1995), 1025 (in Japanese).

9 ) J.Toribio and A.Lancha: J. Mater. Sci., 31(1996), 6015.

10) D.G.Enos and J.R.Scully: Metall. Mater. Trans. A, 33(2002), 1151.

11) E.Proverbio and P.Longo: Corros. Sci., 49(2007), 2421.

12) K.Tomatsu, H.Kawata, T.Amino, T.Omura, N.Maruyama and Y.Nishiyama: ISIJ Int., 57(2017), 564.

13) M.Seo and M.Chiba: Electrochim. Acta, 47(2001), 319.

14) A.Barnoush and H.Vehoff: Acta Mater, 58(2010), 5274

15) K.Tomatsu, K.Miyata and T.Omura: ISIJ Int., 56(2016), 418.

16) T.Doshida and K.Takai: Acta Mater., 79(2014), 93.

17) D.E.J.Armstrong, A.J.Wilkinson and S.G.Roberts: J. Mater. Res., 24(2009), 3268.

18) A.D.Norton, S.Falco, N.Young, J.Severs and R.I.Todd: J. Eur. Ceram. Soc., 35(2015), 4521.

19) Y.Takahashi, H.Kondo, R.Asano, S.Arai, K.Higuchi, Y.Yamamoto, S.Muto and N.Tanaka: Mater. Sci. Eng. A, 661(2016), 211.

20) L.A.Giannuzzi, J.L.Drown, S.R.Brown and R.B.Irwin: Microsc. Res Tech., 41(1998), 285.

21) C.Motz, T.Schöberl and R.Pippan: Acta Mater, 53(2005), 4269.

22) A.V.Syugaev, S.F.Lomaeva and S.M.Reshetnikov: Prot. Met., 44(2008), 51.

23) A.V.Syugaev, S.F.Lomaeva, A.N.Maratkanova, D.V.Surnin and S.M.Reshetnikov: Prot. Met. Phys. Chem. Surf., 45(2009), 81.

24) R.P.Frohmberg, W.J.Barnett and A.R.Troiano: Trans. Am. Soc. Met., 47(1955), 892

25) R.A.Oriani and P.H.Josephic: Acta Metall., 22(1974), 1065.

26) K.Kawakami and T.Matsumiya: ISIJ Int., 53(2013), 709.

27) N.R.Moody, S.L.Robinson and W.M.Garrison: Res Mechanica, 30(1990), 143

28) J.Kameda: Metall. Trans. A, 12(1981), 2039.

29) M.Yamaguchi: Materia Jpn., 54(2015), 111 (in Japanese). 